\title{
Pattern of Smartphone Use Among Clinical Medical Students of Bingham University Teaching Hospital, Jos
}

\author{
Maryam Shehu ${ }^{1, *}$, Hassan Shehu ${ }^{2}$, Michael Bundepuun Ode ${ }^{3}$ \\ ${ }^{1}$ Department of Paediatrics, Bingham University Teaching Hospital, Jos, Nigeria \\ ${ }^{2}$ Department of Surgery, Bingham University Teaching Hospital, Jos, Nigeria \\ ${ }^{3}$ Department of Orthopaedics and Trauma, Jos University Teaching Hospital, Jos, Nigeria
}

Email address:

maryamshehu1405@gmail.com (M. Shehu)

${ }^{*}$ Corresponding author

\section{To cite this article:}

Maryam Shehu, Hassan Shehu, Michael Bundepuun Ode. Pattern of Smartphone Use Among Clinical Medical Students of Bingham University Teaching Hospital, Jos. Central African Journal of Public Health. Vol. 4, No. 5, 2018, pp. 137-142.

doi: 10.11648/j.cajph.20180405.12

Received: August 23, 2018; Accepted: September 6, 2018; Published: October 8, 2018

\begin{abstract}
Background: Mobile phones are one of the most common information access devices with almost $31 \%$ of the global population having access. Mobile phones are now in the hands of 2 billion people out of the 6.47 billion people on this planet. The knowledge on the pattern of use of mobile phones among students will shed more light on the advantages and disadvantages of the use of mobile phones so as to find ways of channeling the usage into being more beneficial and useful to the students. The aim is to determine the pattern of use of smartphones among clinical medical students in Bingham University Teaching Hospital, Jos. The study was a cross- sectional descriptive study among medical clinical students of BHUTH, Jos. The sampling method was consecutive sampling of all the students until sample size was obtained. A total of 134 questionnaires were distributed and all 134 were duly filled and returned. Results: The analyses of the pattern showed that majority of the students spend more than three hours on their phones per day. The commonest applications in use by the students include; Google play store, word documents and blogging applications. Thirteen $(10.2 \%$ spends $>20$ hours $)$ on academic sites, while $(6.0 \%$ spends $>20 \mathrm{hrs})$ on chatting sites, and $(5.7 \%$ spends $>20 \mathrm{hrs})$ on social networking sites per week. A lot of students put their phone on vibration during lectures and there is a gender difference in the use of mobile phone. About one third of the students use their phones at night and most agreed that it is a form of distraction. The study concludes by recommending seminars on the appropriate use of mobile phone in the university.
\end{abstract}

Keywords: Smartphone, Use, Clinical, Medical, Students, Jos

\section{Introduction}

Smartphones are a category of mobile devices that provides advanced capabilities beyond a typical mobile phone. A smartphone is a handheld personal computer with a mobile operating system and an integrated mobile broadband cellular network connection for voice, SMS, and Internet data communication. Most, if not all, smartphones also support Wi-Fi. Smartphones are typically pocket-sized [1]. They are able to run a variety of software components, known as "apps". Most basic apps (e.g. event calendar, camera, web browser) come pre-installed with the system, while others are available for download from official sources like the Google
Play Store or Apple App Store [1].

Mobile phones are used for different purposes. For instance, they are very helpful in keeping in touch with family members, especially parents who worry about the whereabouts of their children. They help them to check on their children easily. Communication is thus enhanced, and anxiety has been reduced over one's loved ones. Instructions and messages are now received promptly and immediately. In fact, it has made the world to function as a global village [2].

The youths, who are college students, make up a large percentage of smartphone users [3]. They are usually the first to know about the latest news and happenings in sports, fashion, entertainment and otherwise. Smartphones provides 
them the opportunity to keep in touch with friends to share the latest things happening in their lives and around the world, every hour, minute and second if possible [4]. According to the study done by Chen and Katz, a lot of students gave the reason why they needed smartphones was to keep in touch with friends and family.[5] Mutula SM et al reported that $90 \%$ of the university students at seven universities in Japan owned cell phones capable of sending and receiving e-mail messages [6]. This shows that students use cell phones for short message communication because the service is cheap, convenient and provides the flexibility of communication from anywhere anytime.

Smartphones are also used for socialization. Ashiq $\mathrm{H}$ et al [7] noted that mobile phone is rapidly becoming an important tool for social connection and helps to maintain and manage social relationships. Ling and Yittri [8] claimed that the adoption of mobile phones resulted in new form of interaction called "micro-coordination and hypercoordination". According to them, micro-coordination refers to the use of cell phones by social groups to coordinate their meeting time and /or place as the need arises while hypercoordination goes beyond the ordinary time/place coordination and includes emotional and social communication among group members and development of group norms for appropriate self-presentation. The availability of social applications such as Facebook, twitter, whatsapp, yahoo messenger, and so on makes social networking very easy. There is another use of cell phone that has been gaining grounds especially among youths: the use of cell phone for entertainment. Smartphones have applications for games, video streams and music. Entertainment apps dominate smartphones both in terms of time spent by consumers and data usage, according to new figures [9].

The reason why the use of smartphones is gaining so much ground among the youths than the older generation is not only because of it is a means of communication but because the youths are more disposed to changing fashion trends and styles [10]. Another very important use of smartphones is for m-learning. Definitions of mobile learning are numerous. Lefrere Pet et al defines mobile learning as a learning that happens when students are not on a fixed location, or a learning that happens when students use learning possibilities of mobile technologies [11]. Other definition describes mlearning as learning through different contexts, through social and content interactions, using personal electronic devices. Context in this definition means learning that is "formal, selfdirected and spontaneous [12]. Muyinda PB et al [13] claimed that in the sphere of education, mobile phones have led to the evolution of new pattern known as mobile learning or m-learning. Mobile phones can be used to help students access web based contents, remix it, share it, collaborate with others and create media rich deliverable for the classroom teachers as well as global audience [14]. In the last twenty years a great number of educational materials become available on the internet: books, scientific researches, presentations, video tutorials, educational games.
Despite the advantages and the benefits of using a smartphone, some studies have shown that smartphone has some negative effects. Study done by Sofowora et al [15] showed that smartphone is being used among college students for examination malpractices, mobile bullying, and indiscipline. Amali I.O et al [16] in their study revealed that mobile phone has become a source of distraction, since students who are expected to commit their time to academic activities, instead commit their time and energies to the various applications in the mobile phones during lectures.

Previous studies have shown that gender may affect the usage of cell phones. Geser H [17], concludes that 'the motivations and goals of cell phone usage mirrors rather conventional gender roles'. He stated that men see phones as instruments that can help them to achieve a goal while women see phones as a social tool. Junco R et al [18] also revealed that female college students engage in more social activities that will foster and maintain relationships like texting, emails and calling than the male counterparts. In a similar study of Facebook addiction, Kuss and Criffiths [19] also found that female adolescents tend to use social media largely to communicate with their friends and families more than male adolescents. However in a study done by Adegbija M.V et al [20] on the academic use of smartphone, there was no significant difference between the male and the female students on the use of cell phones as an academic tool.

The aim of this study was to determine the pattern of usage of smartphones among clinical medical students in Bingham University Teaching Hospital, Jos.

\section{Materials and Methods}

This is a cross-sectional descriptive research of the survey type. The survey involved the use of a researcher-designed questionnaire used to collect data from randomly selected clinical students of Bingham University Teaching Hospital; Jos, consecutively until the sample size was obtained. Informed consent was obtained from the students. The proposal for this study was approved by the Ethical committee of the Teaching Hospital. A total of 134 clinical students responded to the researcher-designed questionnaire

The data was analysed using SPSS statistical package version 20 . Frequency tables and charts were drawn to show the pattern of phone use while Chi-square was used to test for the association between phone use and gender.

\section{Results}

A total of 134 students were enrolled. There were 80 $(59.7 \%)$ females and $54(40.3 \%)$ males giving a male to female ratio of 1:1.48. Of the total number of students enrolled for the study, 133 (99.25\%) owned a smartpnone, while only $1(0.75 \%)$ did not own a smartphone.The major reasons why the students owned smartphones were to keep in touch with family and friends $27.2 \%$, closely followed by academics $25.6 \%$, to pass information $24.7 \%$ and entertainment $22.6 \%$. Table 1 . 
Table 1. Reasons for owing a smartphone.

\begin{tabular}{lll}
\hline Reasons & Frequency & Percentage \\
\hline To keep in touch & 119 & 27.2 \\
Academics & 112 & 25.6 \\
To pass information & 108 & 26.7 \\
Entertainment & 99 & 22.6 \\
Because everyone I know has one & - & - \\
Total & 438 & 100 \\
\hline
\end{tabular}

Eighty-seven $(65.4 \%)$ of the students spend more than four hours on their phones daily and only $6(4.5 \%)$ spend less than one hour on their phones. Table 2.

Table 2. The number of hours spent on smartphones daily.

\begin{tabular}{lll}
\hline Hours & Number & Percentage \\
\hline$<1$ Hour & 6 & 4.5 \\
1-2 Hours & 24 & 18.1 \\
$>2-3$ Hours & 16 & 12.0 \\
$>4$ Hours & 87 & 65.4 \\
Total & 133 & 100 \\
\hline
\end{tabular}

One hundred and one $(83.5 \%)$ of the students use their smartphones to surf the net daily while only $2(1.5 \%)$ surf the net twice a week. Table 3 .

Table 3. The number of times spent on smartphones to surf the net weekly.

\begin{tabular}{lll}
\hline No. of times & Number & Percentage \\
\hline $2 \mathrm{X}$ & 2 & 1.5 \\
$3 \mathrm{X}$ & 6 & 4.5 \\
$5 \mathrm{X}$ & 14 & 10.5 \\
$7 \mathrm{X}$ & 111 & 83.5 \\
Total & 133 & 100 \\
\hline
\end{tabular}

One hundred and twenty eight (23.1\%) of the 554 multiple responses had Google play store application on their phones, closely followed by one hundred and twenty two (22.0\%) having a read document application, the least application was blogging with only thirty one $(5.6 \%)$ of students having it in their phones. Figure1.

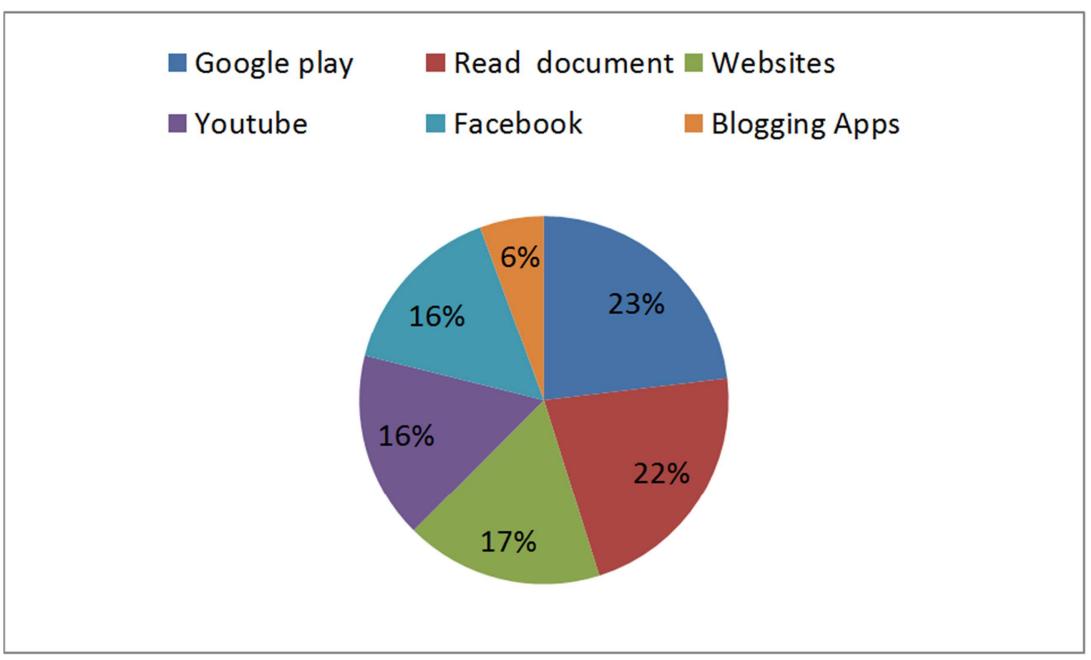

Figure 1. Types of application used on phone.

From their responses using the most number of hours spent on sites per week, $(10.2 \%$ spend $>20$ hours $)$ on academic sites, while $(6.0 \%$ spend $>20 \mathrm{hrs})$ on chatting sites, and (5.7\% spend $>20 \mathrm{hrs}$ ) on social networking sites per week. Table 4.

Table 4. Number of hours spent on sites per week.

\begin{tabular}{lll}
\hline Variable & Number & Percentage (\%) \\
\hline Chatting & & \\
$<5$ hour & 61 & 52.6 \\
$5-10$ hours & 29 & 25.0 \\
$11-15$ hours & 16 & 13.8 \\
$16-20$ hours & 3 & 2.6 \\
$>20$ hours & 7 & 6.0 \\
Total & 116 & 100.0 \\
Game & & \\
$<5$ hour & 26 & 63.4 \\
$5-10$ hours & 10 & 24.4 \\
$11-15$ hours & 5 & 12.2 \\
$16-20$ hours & 0 & 0.0 \\
$>20$ hours & 0 & 0.0 \\
Total & 41 & 100.0 \\
Academics & & \\
\hline
\end{tabular}

\begin{tabular}{lll}
\hline Variable & Number & Percentage (\%) \\
\hline$<5$ hour & 34 & 26.8 \\
$5-10$ hours & 41 & 32.3 \\
$11-15$ hours & 29 & 22.8 \\
$16-20$ hours & 10 & 7.9 \\
$>20$ hours & 13 & 10.2 \\
Total & 127 & 100.0 \\
Social Network & & \\
$<5$ hour & 46 & 43.8 \\
$5-10$ hours & 30 & 28.6 \\
$11-15$ hours & 18 & 17.1 \\
$16-20$ hours & 5 & 4.8 \\
$>20$ hours & 6 & 5.7 \\
Total & 105 & 100.0 \\
\hline
\end{tabular}

Sixty-five $(46.8 \%)$ of the students put their phones on silent during lectures, while another $56(40.3 \%)$ of the students put their phones on vibration, none of the students put their phone on the ring mode. However 48(36.1\%) of the students put their phones on the vibration mode at night, followed by $46(34.6 \%)$ on the ring mode and only $10(7.5 \%)$ of the students put their phones off at night. Table 5 . 
Table 5. Phone notification mode during lectures and at night.

\begin{tabular}{lllll}
\hline \multirow{2}{*}{ Mode of phone } & Lectures & & Night & Percentage (\%) \\
\cline { 2 - 5 } & Number & Percentage (\%) & Number & 21.38 \\
\hline Silent & 65 & 46.8 & 29 & 36.1 \\
Vibrate & 56 & 40.3 & 48 & 34.6 \\
Ring & 0 & 0.0 & 46 & 7.5 \\
Off & 5 & 3.6 & 10 & - \\
I don't bring it to class & 13 & 9.3 & - & 100 \\
Total & 139 & 100 & 133 & \\
\hline
\end{tabular}

There were 596 responses for the different advantages of smartphone use as against 331 respondents for the different disadvantages of smartphone use. However the highest percentage was distraction (32.3\%), which was perceived as a disadvantage. Table 6 .

Table 6. Perception of advantages and disadvantages of smartphone by the students.

\begin{tabular}{|c|c|c|c|c|c|}
\hline & \multicolumn{2}{|l|}{ Advantage } & & \multicolumn{2}{|c|}{ Disadvantage } \\
\hline & Frequency & $\%$ & & Frequency & $\%$ \\
\hline Information is accessible anytime anywhere & 113 & 19.0 & Distraction from studies & 107 & 32.3 \\
\hline Educative & 110 & 18.5 & Needs a network & 70 & 21.2 \\
\hline Improve searching skills & 107 & 18.0 & Expensive & 52 & 15.7 \\
\hline Speedy information access & 92 & 15.4 & Reduces social Interaction & 47 & 14.2 \\
\hline Entertainment & 91 & 15.1 & Easily damaged & 34 & 10.3 \\
\hline Portable device & 83 & 14.0 & Small screen & 21 & 6.3 \\
\hline
\end{tabular}

The percentages of males using their phones for academics were more than the females, $51 \%$ as against $49.7 \%$, but the difference was not statistically significant with p value of 0.839 . Table 7 .

Table 7. Gender differences in the use of smartphones.

\begin{tabular}{llll}
\hline & Academics (\%) & Others & Total \\
\hline Male & $53(51.0)$ & $51(49.0)$ & $104(100)$ \\
Female & $73(49.7)$ & $74(50.3)$ & $147(100)$ \\
Total & 126 & 125 & 251 \\
\hline
\end{tabular}

$\chi^{2}=0.041$, others $=$ chatting, games and social networking.

\section{Discussion}

In this study the prevalence of the ownership of smartphone was $99.3 \%$ and the male to female ratio was 1 : 1.48 which is similar to that obtained by Mamudu P.A and Oyewo A.O [21] in the study of the use of mobile phone for academic purposes by Law students of Igbinedion University, Okada Nigeria. All the students (100\%) owed smartphones and the male to female ratio was 1:1.31.

The major reason for the purchase of smartphones by the students in this study was to keep in touch with friends and families and for academics, none of the students got a smartphone because of peer influence or because it is what everyone is doing. These could because of the fact that, majority of the students are clinical medical students and they need to study hard. This is similar to the study done by Mamuda P.A et al where the major reasons for acquiring a smartphone was for academics and communication [21].

In this study about $65 \%$ of the students spend more than four hours daily on their phones and further information revealed that over $80 \%$ of the students surf the net about seven times a week. The applications on their smartphones are mostly Google play store which could be used to download a lot of entertainment, communication and other social networking applications. The second most available application is the read document application which can be used to do a lot of academic activities like reading, studying and writing assignments. This can be compared to what was obtained in the study done by Mamudu et al [21] were about $48 \%$ of the students spend more than three hours on their phones daily and greater than $80 \%$ also surf the net seven times a week.

Using the most number of hours spent on different sites, thirteen $(10.2 \%$ spend $>20$ hours on academics sites per week, while seven $(6.0 \%$ spend $>20$ hours) on chatting sites and six (5.7\% spend $>20$ hours) on social networking sites per week. When the average number of hours spent on chatting, social networking and games are combined together, the total will be much more than that spent on academics. This could be related to the results gotten earlier where the main reason why they bought smartphone was to keep in touch with friends and families. The results is similar to what was gotten by Mamuda et al [21] where the total number of hours spent on chatting, social networking, shopping, gambling, news and games is much more than that spent on academics.

The mode the students keep their phones on during lectures and at night revealed that $48.5 \%$ keep it in silence 
and $41.8 \%$ keep in on vibration during lectures while $35.1 \%$ kept their phone on vibration at night and $34.3 \%$ kept it on ring. This is in contrast to what Amali I.O.O et al [16] got in the University of Ilorin, where majority of the students use their mobile phones for listening to music, texting, browsing, playing games, listening to the radio, using the calculator and snapping pictures during lectures. A plausible explanation could be because the study in Ilorin was done in the faculties of Education and Agriculture in 100-400L students, while this study was done in the college of medical and clinical sciences in 400-600L students.

A high percentage of the students $(32.3 \%)$ believe that phone can be a source of distraction as against (18.5\%) who believes that it can be educative. The results gotten fron Amali et al [16] and Ajihadun et al [2] also revealed that smartphones can be a source of distraction during lectures and at night during sleep respectively, It can infact lead to addiction.

This study also revealed that there is no gender difference in the use of smartphone in terms of academics compared to other communication and entertainment uses. This could be because of the students are all medical students where gender is not considered as they all have to study hard, be brave and consistent. This is similar to what was obtained in the study done by mosiforeba et al [20] when they compared the perceived adoption of mobile technologies for learning between males and females, which was not statistically significant. However this is in contrast with what was gotten by Geser H [17], Junco R et al [18] and Kuss et al [19] in which they all found gender difference in the social use of mobile phone. This could be explained by the fact that the females are said to be more communication lovers than males.

\section{Conclusion}

The above study revealed that the major reason why students buy smartphones is to keep in touch with friends and family members, and then secondly for academics. About two thirds of the students spend a lot of their time on their phones daily surfing the net, and they also spend more time on chatting and social networking than on educative sites. Some of the students also believed that it can be a source of distraction from their academics. There is therefore a need for an orientation program on the proper and educative use of smartphones, so that the students will use their smartphones more for academics than for chatting and social networking so as to avoid making the smartphone serve as a source of distraction.

\section{References}

[1] Smartphone. Wikipedia. Available from: http://en.wikipedia.org/wiki/smartphone [Accessed $6^{\text {th }}$ May, 2018].

[2] Ajidahun BO. Students' Perceptions of Cell Phones and Emotional Behaviour of Undergraduates in Nigerian Universities. J Edu Soc Res 2014;4:183-90.
[3] Bhutia Y, Tariang A. Mobile Phone Addiction Among College Going Students in Shillong. Int J Educ Psychol Res 2016;5:29-35.

[4] [4] Olaitan W.A, Olusegun J. O. Analysis of the attitude of college students towards mobile phone usage in Nigeria. Inter J Educ Learn Dev 2017;5:1-19.

[5] Chen Y, Katz J.E. Extending Family to School Life: College Students' Use of Mobile Phone. Available from: http://www.allacademic.com/meta/p171018_index.htm. [accessed $10^{\text {th }}$ May, 2018].

[6] Mutula SM, Komanyane K, Grand B. "Cell phone use by students at the University of Bostwana: a comparative study of Library and information studies" and other departments". Afr J Lib Arch Infor Sci 2005; 15: 81-5.

[7] Ashiq H, Mahmood MT, Siraj AS. Use of Mobile Communication and its Effect on Social capita of College Going Teenager. Inter J Res Huma Arts Lit. 2013; 1: 45-60.

[8] Ling R, Yttri B. Nobody Sits at Home and Waits For The Telephone to Ring: Micro and Hyper-Coordination Through The Use of The Mobile Telephone. Available from: http://www.telenor.no/fou/prosjekter/Fremtidens_Brukere [Accessed 6th May 2018].

[9] European Communication. Entertainment app dominates smartphone usage, report finds. Available from: https://eurocomms.com/.../12289- [Accessed 6th May, 2018].

[10] Mackay M.M, Weidlich, O. Australian Mobile Phone Lifestyle Index (3rd ed.). Sydney 2007: Australian Interactive Media Industry Association.

[11] Lefrere P, Malley C. O, Sharples M. Producing guidelines for learning, teaching and tutoring in a mobile environment. Available from: http://doi.org/10.1109/WMTE.2004.1281378 [ Accessed 10 $0^{\text {th }}$ May 2018].

[12] Crompton, H. A historical overview of mobile learning: Toward learner-centered education. Handbook of Mobile Learning, 2013: p 3-14.

[13] Muyinda PB, Mugisa E, Lynch KM-Learning: The Educational Use of Mobile Communication. In: Migga KJ, Muhirwe J, Aisbett J, Getao K, Mbarika WW, Patel D,Rodrigues AJ. (eds). Strengthening The Role of ICT in Development. Available from: http://wikieducator.org/images/6/6c/PID_81.pdfdevices [Accessed 6th May,2018].

[14] Ferry B. Using Mobile Phones to Enhance Teacher Learning in Environmental Education. In Herrington J, Herrington A, Mantei J. Olney I, Ferry, B. (eds), New Technologies, New Pedagogies: Mobile Learning in Higher Education. Faculty of Education, 2009: 45- 65.

[15] Sofowora O.A. Mobile Phone Adoption: Its Influence on Social Behavior, Schooling and Academic Work of Adolescent Students in Osun State, Nigeria. Malaysian Journal of Educational Technology. Available from: http://www.mjet-meta.com/resources/V11. [ Accessed $12^{\text {th }}$ May 2018].

[16] Amali I.O.O, Bello M, Hassan I. A survey of University of Ilorin students' use of mobile phone in lecture room and its implication in education for Nigeria development. J Educ Prac $2012 ; 3: 1-10$. 
[17] Geser H. Are Girls (even) More Addicted? Some Gender Patterns of Cell Phone Usage. Sociology in Switzerland: Sociology of the Mobile Phone. Available from: http://socio.ch/mobile/t_geser3. [ Accessed 12 ${ }^{\text {th }}$ May 2018].

[18] Junco R, Merson D, Salter D. W. The Effect of Gender, Ethnicity, and Income on College Students' Use of Communication Technologies. Cyber Psychology \& Behaviour 2006;13: 619-627.

[19] Kuss, D. J. \& Griffiths, M. D. (2011). Excessive Online Social Networking: Can Adolescents Become Addicted to Facebook? Education and Health, 29(4), 68-71.
[20] Mosiforeba Victoria Adegbija \&Olaniyi Oladimeji Bola Perception of undergraduates on the adoption of mobile technologies for learning in selected universities in Kwara state, Nigeria. Procedia - Social and Behavioral Sciences 176 (2015) $352-356$.

[21] Mamudu P. A, Oyewo A.O. Use of Mobile Phones for Academic Purposes by Law Students of Igbinedion University, Okada Nigeria. Inter J Lib Sci 2015;4: 65-72. 